\title{
Improvement of the Rheological Properties of Local Bentonite Clay Using New Blending Polymers for Water - based Drilling Fluids
}

\author{
M.M. Dardir ${ }^{\#}$, S. Ibrahim, A. Awadallah**, Soad Y. Abd \\ EL-Wahab $^{* *}$ and H.I. Al-Shafey* \\ Production Department- Drilling Fluids Laboratory, " Applied \\ Department- Additive Laboratory, Egyptian Petroleum

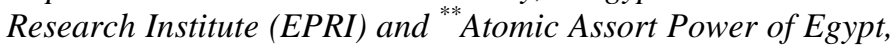 \\ Cairo, Egypt.
}

\begin{abstract}
EW composition polymers formulated from the reaction of different mixed polymers by using gamma $(\gamma)$ radiation technology. A fixed ratio of polyvinylalchol (PVA), chitosan was mixed with different ratios of N-vinyl-2-pyrolidene (NVP) with and without diethyleglycal dimethylacrylate (DEDMA). The chemical structures of the prepared composition polymers were conformed using FT-IR and the molecular weight determination by (GPC). The results of the spectroscopic analysis indicate that they were prepared through right method and they have high purity. The new prepared composition polymers were evaluated as a viscosifier and filter loss additives for water-based drilling fluid formulated from local Egyptian clay to improve their rheological properties. The evaluation includes the study of rheological, filtration of the water - based mud treated with the new prepared composition polymers and the results were compared to the reference commercial water based- mud. The results of treatment of water-based mud with the prepared new composition polymers showed a good efficiency.
\end{abstract}

Keywords: Water-based mud, Poly vinyl alcohol (PVA), Chitosan, Rheological properties and Filtration properties.

During drilling of oil and gas wells, fluids are used to lubricate the drill bit, maintain hydrostatic pressure, transmit sensor reading, remove rock cuttings and inhibit swelling of reactive clay based shale formations ${ }^{(1-4)}$. Aqueous drilling fluids (water-based mud) are an environmental friendly and more economic than the non-aqueous type (oil - based mud and synthetic - based mud ) ${ }^{(5-11)}$. In order to achieve the optimum performance of any mud during drilling operations, the physical as well as chemical properties of the mud must be carefully controlled ; viscosity, gel strength, fluid loss are of particular importance (parameters of drilling fluids). Also, the clay surface chemistry and that of various drilling fluids constitute must be controlled ${ }^{(12-14)}$. To control all these parameters simultaneously and restore the desired drilling fluid propertiesce it becomes necessary to use various chemicals as additives. Growing pressure is being placed upon oil and gas exploration industry to develop drilling fluid, additives with lower environmental impact. Long chain, high molecular weight chemicals

\footnotetext{
${ }^{\#}$ Corresponding author: E-mail: monamdardir@yahoo.com
} 
are effective in increasing viscosity, flocculating molecule, reducing filter loss and stabilizing the formation. Various types of polymers are suitable for this purpose including bentonite extenders; biopolymers and cross-linkers polymers are also used and have good shear-thinning properties at low concentration ${ }^{(15-21)}$.

Bentonite is the main constituent of the water-based drilling fluids due to high viscosity good swelling and lower filter loss. Local raw bentonite exhibit high filtration loss and do not develop sufficient viscosity so, they cannot meet the API (30cp minimum viscosity at $600 \mathrm{rpm}, 15 \mathrm{~cm} 3$ filtration loses) standards ${ }^{(22)}$. By alkali activation or by introducing some polymer additives it is possible to upgrade row bentonite to meet the above standards and thus require appropriate activation formulations. This activation typically employs various additives such as inorganic salts like soda ash, Mgo salt; the inorganic salt improves the swelling or viscosity ${ }^{(23-25)}$. In the oil drilling fluid field, the polymer is usually selected to reduce fluid loss, increase cutting carrying capacity serve as emulsifiers and lubricants, especially as shale inhibition additives in water-based mud. Modification of bentonite with polymers (soluble in water) and similar compounds has been studied by different investigators and outstanding rheological behaviors such as viscosity, thixotroply, ...etc. have been measured. Mechanisms governing activation can be usually advanced as ion exchange, ion adsorption and particle interaction (hetirocogulation) ${ }^{(26-28)}$. Organic compounds in particle - particular polymers, generally are more effective additives than inorganic salts. Polymeric materials are generally considered useful as viscosifiers agent and water loss additive when dissolved in appropriate solve system.

The interaction of non-ionic polymers with the clay surface is possible through two types of polymers. The amount of water bound the montmorillomite surface increases laniary with the concentration of oxygen or hydroxyls. There are two mechanisms, ion-dipole interactions, where the saturating cations on the clay surface serves as adsorption site for polar-non-ionic molecules. The second type of interaction involves hydrogen bonding either by the direct interaction between the adsorbed polymer clay surface and polymers ${ }^{(29-32)}$.

The aim of this work is to prepare a new composition polymers formulated from the reaction of different mixed polymers by using gamma $(\gamma)$ radiation technology. A fixed ratio of polyvinylalchol (PVA), chitosan was mixed with different ratios of N-vinyl-2-pyrolidene (NVP) with and without diethyleglycal dimethylacrylate (DEDMA). The new prepared composition polymers was evaluated as a viscosifier and filter loss additives for water-based drilling fluid formulated from local Egyptian bentonite clay to improve their rheological properties. The evaluation includes the study of rheological, filtration of the water - based mud treated with the new prepared composition polymers and the results were compared to the reference commercial water based- mud.

Egypt. J. Chem. 59, No. 1 (2016) 


\section{Experimental Materials}

\section{Materials}

All chemicals that were used throughout this investigation are of analytical grade and used as they are without more purification. Poly vinyl alcohol (PVA) with a molecular weight about 14000, vinyl pyrrolidone (PNVP) with average molecular weight 40000, chitosan and diethylene glycol dimethacrylate (DEDMA) were purchased from sigma Aldrich.

\section{Preparation of the PVA/Ch/NVP Polymer through Radiation Method}

Different samples were prepared from various components; full hydrolyzed poly vinyl alcohol (PVA), chitosan, N-vinyl-2-pyrrolidone (NVP) and diethylene glycol dimethacrylate (DEDMA). The preparation of PVA and chitosan solutions was aforementioned elsewhere ${ }^{(33-36)}$. The composition of each sample was listed in Table 1. The samples solutions were mixed and poured into test tubes of diameter $15 \mathrm{~nm}$ and then irradiated with gamma rays and exposed to $30 \mathrm{k}$ Gy of a fixed dose rate $2.43 \mathrm{kGy} / \mathrm{h}$. It was observed that, the samples extracted from gamma irradiation cell were characterized with light viscous with white foggy color. The extracted samples were casted on to Petri-plates $\left(25 \mathrm{~cm}^{2}\right)$ and put in oven at $40{ }^{\circ} \mathrm{C}$ and 1 bar to dry. The drying process of samples continued for 5 days.

TABLE 1. The component of different samples during preparation.

\begin{tabular}{|l|c|c|c|c|c|}
\hline $\begin{array}{l}\text { Sample } \\
\text { code }\end{array}$ & $\begin{array}{c}\text { PVA } \\
\mathbf{( 8 \% )} \\
(\mathbf{g} / \mathbf{v})\end{array}$ & $\begin{array}{c}\text { Chitosan } \\
(\mathbf{1 \%})(\mathbf{g} / \mathbf{v})\end{array}$ & $\begin{array}{c}\text { NVP } \\
(\mathbf{1 0 \%}) \\
(\mathbf{v} / \mathbf{v})\end{array}$ & DEDMA (1\%) (v/v) & Mwt \\
\hline $\mathrm{S}_{1}$ & $5 \mathrm{ml}$ & $1.5 \mathrm{ml}$ & $4.5 \mathrm{ml}$ & $1 \mathrm{ml}$ & 857 \\
\hline $\mathrm{S}_{2}$ & $5 \mathrm{ml}$ & $1.5 \mathrm{ml}$ & $6.0 \mathrm{ml}$ & $1 \mathrm{ml}$ & 859 \\
\hline $\mathrm{S}_{3}$ & $5 \mathrm{ml}$ & $1.5 \mathrm{ml}$ & $4.5 \mathrm{ml}$ & ---- & 891 \\
\hline
\end{tabular}

Characterization of $P V A / C h / N V P$

The chemical structures of the prepared polymers S1,S2 and S3 were confirmed by: FT-IR spectra of the superabsorbent composite were recorded on a Nicolet-380 Fourier Transform Infrared Spectrometer in a range of 4000-400 $\mathrm{cm}^{1}$ using $\mathrm{KBr}$ pellets as shown in Fig. 1 .

\section{Sample collection and preparation}

The field sampling exercise was carried out during the dry season. Fresh samples of the local clay were collected from South Hamam Egypt. The samples were crushed to finer particles and sundried for 5 days to ease pulverizing and sieving. Then they were ground to powder with the aid of mortar and pastle, and then sieved with a rota shaker to obtain $63 \mu$ fractions to Suit API specification for local bentonite ${ }^{(37)}$. 
Mineralogical studies

$X$-ray diffraction (XRD)

Mineralogical composition of the local bentonite before and after treatment with the new prepared blending polymers S1,S2 and S3 as viscosifiers by X-ray diffraction (XRD) using a philips X-ray diffraction equipment model Pw 710 with mono chromator, $\mathrm{Cu}$ radiation $\left(\mathrm{h}=1.542 \mathrm{~A}^{\circ}\right)$ at $40 \mathrm{kV}, 35 \mathrm{~mA}$ and scanning speed $0.02^{\circ} \mathrm{s}$. The reflection peaks between $2 \varnothing=2^{\circ}-70^{\circ}$, corresponding spacing $\left(\mathrm{d}, \mathrm{A}^{\circ}\right)$ and the relative intensities $\left(\mathrm{I} / \mathrm{I}^{\circ}\right)$ were obtaine ${ }^{(38)}$. The diffraction charts and the relative intensities were obtained and compared with ICDD files (Table 2).

$X$-ray fluorescence $(X R F)$

The samples studied are carried out to determine the chemical composition by (XRF) Spectrometry ${ }^{(37)}$ and the results were listed in Table 3.

\section{Tests for water-based mud}

\section{Mud formulation}

All sample were prepared according to American petroleum institute [API RP 13B-1 1997] ${ }^{(22)}$ and oil companies petroleum institute [OCMA specification No. DFCP-4 1983] ${ }^{(39)}$. Mud was formulated as following:

1 - The base component of water based mud was prepared by adding $6 \%$ of local bentonite mixed with $500 \mathrm{ml}$ fresh water.

2- The samples were mixed in Hamiltan mixer for 20 min and cured overnight.

3- The samples were stirred for $15 \mathrm{~min}$ then the rheological and filtration properties were measured before adding the viscosifier.

4- Different concentrations of the new prepared blending polymers $S_{1}, S_{2}$ and $S_{3}$ were separately added to mud batches and stirred for $20 \mathrm{~min}$ and cured overnight.

5- Each sample was stirred for $5 \mathrm{~min}$ before the rheological and filtrations properties were measured. So we have five mud batches:

$\mathrm{M}_{\mathrm{R}}$ : Water -based Mud formulated of $6 \%$ commercial bentonite $(\mathrm{R})$.

$\mathrm{M}_{0}$ : Water -based Mud formulated of $6 \%$ Local non-treated bentonites.

$\mathrm{Ms}_{1}$ : Water-based Mud formulated of 6\% Local non-treated bentonite and different concentrations of the prepared polymer $S_{1}$ ranged from 0.1 to $0.9 \mathrm{~g}\left(\mathrm{~S}_{1}\right)$.

$\mathrm{Ms}_{2}$ : Water-based Mud formulated of $6 \%$ Local non-treated bentonite and different concentrations of the prepared polymer $S_{2}$ ranged from 0.1 to $0.9 \mathrm{~g}\left(\mathrm{~S}_{2}\right)$.

$\mathrm{Ms}_{3}$ : Water-based Mud formulated of 6\% Local non-treated bentonite and different concentrations of the prepared polymer $S_{3}$ ranged from 0.1 to $0.9 \mathrm{~g}\left(\mathrm{~S}_{3}\right)$.

\section{Rheological properties}

Rheological properties of the water-based mud were measured by using chandler engineering laboratory model (API) viscometer Chan 35 Model (3500). Apparent viscosity (AV), plastic viscosity (PV) and yield point (YP) Unit of: PV in centipoises (cP), AV in centipoises $(\mathrm{cP})$ and $\mathrm{YP}$ in $1 \mathrm{~b} / 100 \mathrm{ft}^{2}$ were measured. 


\section{Determination of gel strength and thixotropy}

The gel strength of the water-based mud is a measure of the minimum shearing stress necessary to produce slip-wise movement of fluid. Two readings are generally taken (1) after $10 \mathrm{sec}(\mathrm{G} 10 \mathrm{sec})(2)$ after the mud in the cup has been rested for $10 \mathrm{~min}$ (G10 $\mathrm{min}$ ). Thixotropy of the mud is the difference between the low reading after $10 \mathrm{sec}$, and $10 \mathrm{~min}$.

\section{Effect of temperature on the rheological properties}

Viscosity of the water-based mud is a function of temperature more than pressure. It is necessary to measure viscosity at elevated bottom whole temperature. This is done by using the viscosity cup heater which is a thermostatcontrolled unit for heating the mud sample directly on a viscometer with the selected concentration that meet the minimum API specifications for rheological properties ( $15 \mathrm{cp}$ for apparent viscosity ) and $13.5 \mathrm{ml}$ for the filtration properties so for $\mathrm{Ms}_{1}$ the selected concentration was $1.4 \mathrm{gm} / 1000 \mathrm{ml}$, for $\mathrm{Ms}_{2}$ was $0.6 \mathrm{gm}$ $/ 1000 \mathrm{ml}$ and for $\mathrm{Ms}_{3}$ was $1 \mathrm{gm} / 1000 \mathrm{ml}$

\section{Filtration properties}

All experimental data were carried out using Standard filter press fan model 300 multichamper for filtration at 100 psi after 30 minutes.

\section{Results and Discussion}

\section{Characterization of $P V A / C h / N V P$}

The chemical structures of the prepared polymers $S_{1}, S_{2}$ and $S_{3}$ were confirmed by: FT-IR spectra of the superabsorbent composite were recorded on a Nicolet-380 Fourier Transform Infrared Spectrometer in a range of $4000-400 \mathrm{~cm}^{-1}$ using $\mathrm{KBr}$ pellets. Figure $1(a, b, c)$ show the FTIR of the prepared compounds $S_{1}, S_{2}$ and $S_{3}$ respectively. In the present study, PVA, $\mathrm{Ch}$, and NVP are compatible and miscible polymers via hydrogen bonds interactions between the $\mathrm{CO}, \mathrm{OH}$ and $\mathrm{NH}_{2}$ groups in the monomers in the amorphous regions of the blends. In the case of three samples, the band at $1670 \mathrm{~cm}^{-1}$ corresponded to the stretching vibration of $\mathrm{C}=\mathrm{O}$ carbonyl group and at $1441 \mathrm{~cm}^{-1}$ the vibration of C-N. The band at $1290 \mathrm{~cm}^{-1}$ was the absorption of $\mathrm{C}-\mathrm{O}$, and that at $2986 \mathrm{~cm}^{-1}$ was ascribed to the $-\mathrm{CH}_{2^{-}}$group on the polymeric produced by polymerization of PVA, $\mathrm{Ch}$, and NVP. The broad band at $3429 \mathrm{~cm}^{-1}$ was ascribed to the -OH groups as shown in Fig. 1 ( a,b,c). 

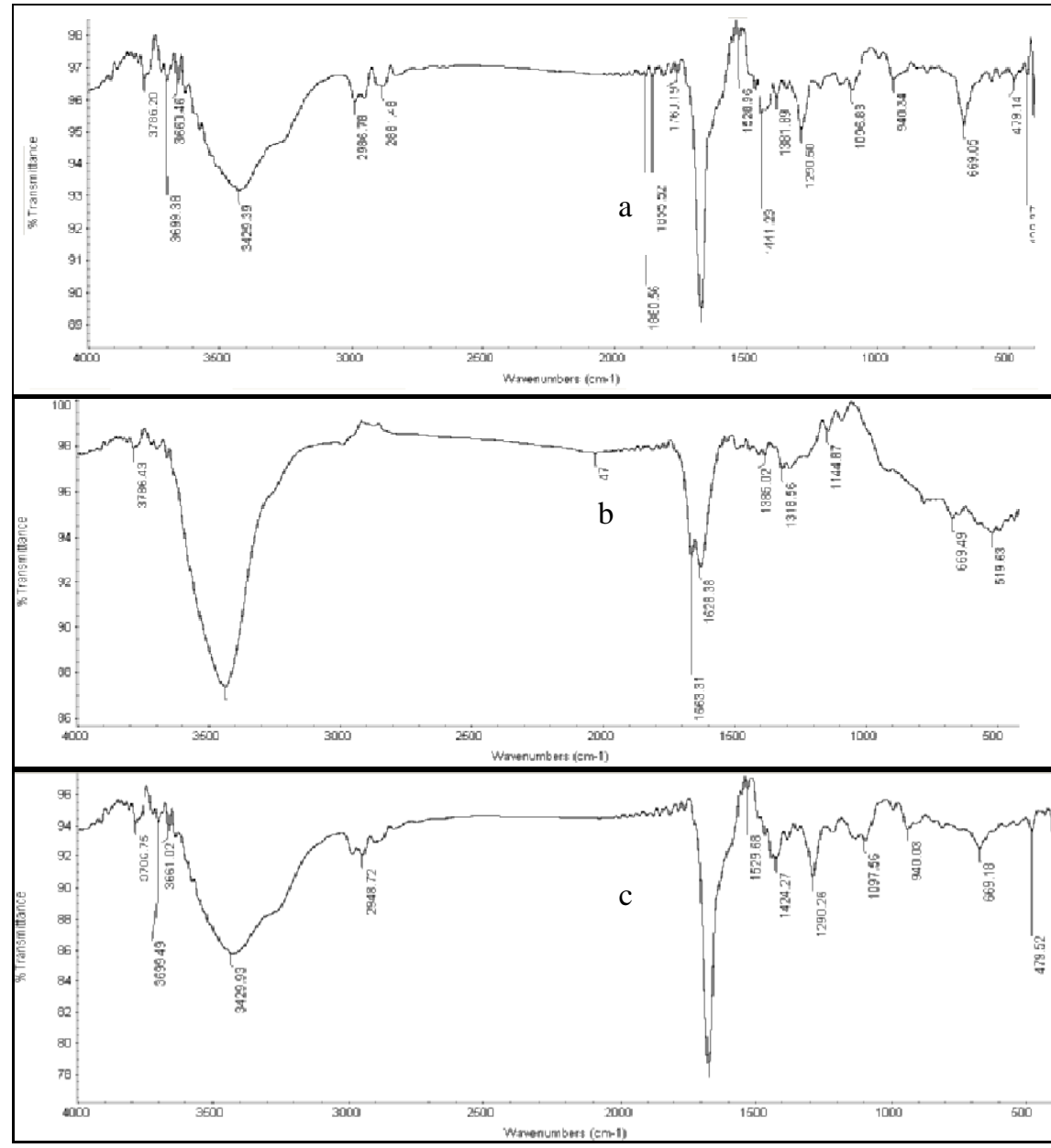

Fig. 1. FTIR spectra of a) $S_{1}$, b) $S_{2}$ and c) $S_{3}$.

Mineralogical studies

The diffraction charts and the relative intensities were obtained and compared with ICDD files as illustrated in Table 2.

TABLE 2. X-ray diffraction analysis for local bentonite .

\begin{tabular}{|c|c|}
\hline Constituents : & Local bentonite \\
\hline Major const : & Montmorillonite, Quartz \\
\hline Minor const : & Kaolinite \\
\hline Trace const : & - \\
\hline
\end{tabular}

Egypt. J. Chem. 59, No. 1 (2016) 
$X$-ray fluorescence $(X R F)$

The chemical composition (XRF) spectrometry results were listed in Table 3.

TABLE 3. Chemical analysis for local-bentonite.

\begin{tabular}{lccc}
\hline Elements & Local-bentonite \% & Elements & Local-bentonite \% \\
\hline $\mathrm{SiO}_{2}$ & 54.91 & $\mathrm{Na}_{2} \mathrm{O}$ & 2.75 \\
$\mathrm{TiO}_{2}$ & 1.53 & $\mathrm{~K}_{2} \mathrm{O}$ & 1.03 \\
$\mathrm{Al}_{2} \mathrm{O}_{3}$ & 17.01 & $\mathrm{P}_{2} \mathrm{O}_{5}$ & 0.16 \\
$\mathrm{Fe}_{2} \mathrm{O}_{3}$ & 9.31 & $\mathrm{Cl}$ & 1.20 \\
\hline
\end{tabular}

From the above results we can conclude that most of the studied samples of bentonite clay, were mainly montmorillonite .

\section{$X$-ray diffraction}

Mineralogical properties of the local raw bentonite clay mo after treatment with the prepared rheological modifiers $\left(S_{1}, S_{2}\right.$ and $\left.S_{3}\right)$ using X-Ray Diffraction (XRD).

In addition to adsorption on to external surface, intercalation also takes place in phyllosilicates. To recognize the MMT intercalation with the new blending polymers $S_{1}, S_{2}$ and $S_{3}$, the XRD patterns of the $\mathrm{MS}_{1}, \mathrm{MS}_{2}$ and $\mathrm{MS}_{3}$ samples were measured compared to the basel spacing of the local untreated clay Mo . The observed basal spacing $\left(d_{001}\right)$ of $\mathrm{MS}_{1}, \mathrm{MS}_{2}$ and $\mathrm{MS}_{3}$ are given in Table 4 and Fig. 2. The $d_{001}$ value of each of $\mathrm{MS}_{1}, \mathrm{MS}_{2}$ and $\mathrm{MS}_{3}$ samples is higher in value than that of the local sample $\mathrm{M}_{0}$.The basel spacing $\left(d_{001}\right)$ value of MS2 is higher than that of $\mathrm{MS}_{1}$ and $\mathrm{MS}_{3}$ which indicates that $\mathrm{S}_{2}$ blending polymer was intercalated in a great amount than $S_{1}$ and $S_{2}$ blending polymers and it is also indicate that $S_{2}$ is attached strongly to the clay. This is because of the higher van dar walls and electrostatic interactions with the negatively charged silicate layers. The order of interaction was $S_{2}>S_{1}>S_{3}$, so the studied clay samples can not be used for the formulation of water based mud without treatment or activation .

TABLE 4. Basal spacing values $\left(d_{001}\right)$ and diffraction angel of the local bentonite treated with $S_{1}, S_{2}$ and $S_{3}$.

\begin{tabular}{lcc}
\hline Material & Basal spacing region $\boldsymbol{d}_{\mathbf{0 0 1}}(\mathbf{\AA})$ & Position $\left(\mathbf{2 \theta}^{\circ}\right)$ \\
\hline $\mathrm{M}_{0}$ & 12.95 & 5.91 \\
$\mathrm{MS}_{1}$ & 13.86 & 5.41 \\
$\mathrm{MS}_{2}$ & 14.05 & 5.81 \\
$\mathrm{MS}_{3}$ & 13.24 & 5.51 \\
\hline
\end{tabular}




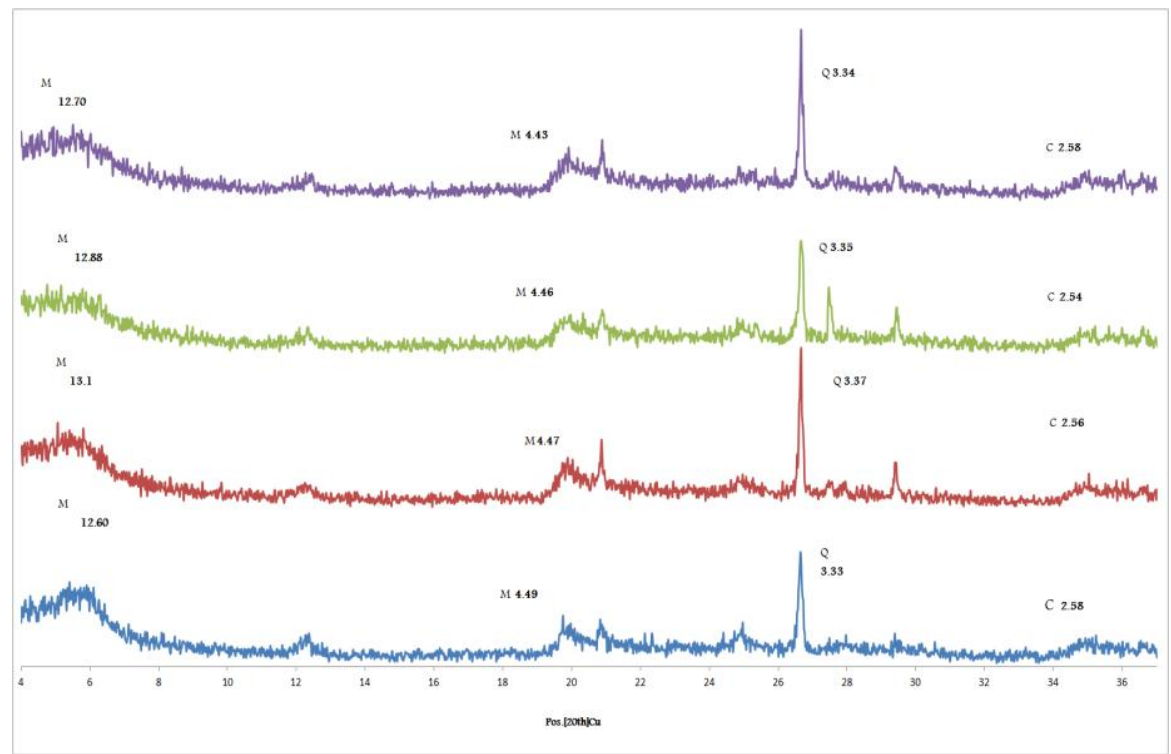

Fig. 2. X-ray diffraction analysis of $\mathrm{MS}_{1}, \mathrm{MS}_{2}$ and $\mathrm{MS}_{3}$ compared to local $\mathrm{M}_{0}$

Rheological and filtration properties of water-based mud treated with prepared polymeric compounds

The rheological properties of the reference mud formulated from commercial bentonite (Mr) and mud formulated with local non treated bentonite (Mo) at $60^{\circ} \mathrm{F}$ were illustrated in Table 5.

TABLE 5. The rheological properties and filter loss of the reference mud $\left(M_{R}\right)$ and local non treated bentonite mud $\left(\mathrm{M}_{0}\right)$.

\begin{tabular}{|c|c|c|c|c|c|c|c|}
\hline \multirow{2}{*}{$\begin{array}{l}\text { Mud } \\
\text { type }\end{array}$} & \multirow{2}{*}{$\mathbf{A V}(\mathbf{c P})$} & \multirow{2}{*}{$\mathbf{A V}(\mathbf{c P})$} & \multirow{2}{*}{$\begin{array}{l}\text { YP(1b/ } \\
\left.100 f^{2}\right)\end{array}$} & \multicolumn{2}{|c|}{$\begin{array}{c}\text { Gel stranght } \\
(1 \mathrm{~b} / \mathbf{1 0 0 f t} 2)\end{array}$} & \multirow[t]{2}{*}{$\begin{array}{l}\text { Thixtropy } \\
\left(\mathbf{1 b} / \mathbf{1 0 0 f t ^ { 2 }}\right)\end{array}$} & \multirow[t]{2}{*}{$\begin{array}{c}\text { Filter loss } \\
\text { MI }\end{array}$} \\
\hline & & & & $\begin{array}{l}\text { G10 } \\
\text { sec. }\end{array}$ & $\begin{array}{l}\text { G10 } \\
\text { min. }\end{array}$ & & \\
\hline $\mathbf{M}_{\mathrm{R}}$ & 22.5 & 5 & 35 & 5 & 5 & 0 & 15 \\
\hline $\mathbf{M}_{0}$ & 9 & 2 & 14 & 2 & 3 & 1 & 25 \\
\hline
\end{tabular}

From the above results we can conclude that the performance of water-based muds formulated from local bentonite don't meet the API specification and the rheological properties need to modify. So on using the new three blending polymers $S_{1}, S_{2}$ and $S_{3}$ as rheological modifier for the local bentonite mud Mo, Tables 6, 7 and 8 illustrated the treatment of water - based mud formulated from the local bentonite with different concentration of the prepared blending polymers $S_{1}, S_{2}$ and $S_{3}$. 
The rheological properties of the water-based mud formulated of $6 \%$ Local non-treated bentonite and different concentrations of the prepared polymer $S_{1}$ ranged from 0.1 to $0.9 \mathrm{~g}$ were illustrated in Table 6 .

TABLE 6. The rheological properties of water based - mud formulated of local bentonite with different concentration of the new prepared polymer $S_{1}$ $\left(\mathrm{MS}_{1}\right)$.

\begin{tabular}{|c|c|c|c|c|c|c|c|}
\hline \multirow{2}{*}{$\begin{array}{l}\text { Mud } \\
\text { type }\end{array}$} & \multirow{2}{*}{$\begin{array}{l}\text { Conc.of } \\
S_{1}(g)\end{array}$} & \multirow[t]{2}{*}{$\mathbf{A V}(\mathbf{c P})$} & \multirow[t]{2}{*}{$\mathbf{P V}(\mathbf{c P})$} & \multirow[t]{2}{*}{$\mathbf{Y P}\left(\mathbf{1 b} / \mathbf{1 0 0 f t ^ { 2 }}\right)$} & \multicolumn{2}{|c|}{$\begin{array}{c}\text { Gel } \\
\text { strength }\left(1 \mathrm{~b} / 100 \mathrm{ft}^{2}\right)\end{array}$} & \multirow[t]{2}{*}{$\begin{array}{l}\text { Thixtropy } \\
\left(\mathbf{1 b} / \mathbf{1 0 0 f t ^ { 2 } )}\right.\end{array}$} \\
\hline & & & & & G10 sec. & G10 min. & \\
\hline \multirow{9}{*}{$\mathbf{M S}_{1}$} & 0.1 & 9.5 & 2.5 & 12.5 & 10 & 12 & 2 \\
\hline & 0.2 & 10 & 3 & 14 & 10 & 12 & 2 \\
\hline & 0.3 & 11.5 & 4 & 15 & 11 & 13 & 2 \\
\hline & 0.4 & 12.5 & 5 & 15 & 12 & 15 & 3 \\
\hline & 0.5 & 13.5 & 4 & 19 & 12 & 16 & 4 \\
\hline & 0.6 & 14.5 & 3 & 23 & 15 & 17 & 2 \\
\hline & 0.7 & 15 & 2 & 26 & 16 & 18 & 2 \\
\hline & 0.8 & 17.5 & 3 & 29 & 18 & 20 & 2 \\
\hline & 0.9 & 18.5 & 2 & 33 & 20 & 23 & 3 \\
\hline
\end{tabular}

From the above results we can conclude that water-based muds which consist of $6 \%$ Local non-treated bentonites and different concentrations of the prepared polymer $S_{1}$ ranged from 0.1 to $0.9 \mathrm{~g}$. showed rheological properties : Apparent viscosity ( $\mathrm{AV}$ ) increase from $(9.5$ to $18.5 \mathrm{cP})$, Plastic viscosity (PV) increase from $(2.5$ to $5 \mathrm{cP})$

Yield point (YP) increased from (12.5 to $\left.331 \mathrm{~b} / 100 \mathrm{ft}^{2}\right)$ as the concentrations of the prepared polymer $S_{1}$ increased from $(0.1$ to $0.9 \mathrm{~g})$.

The gel strength $\mathrm{G} 10_{\mathrm{sec}}$.ranged between (10 to $\left.201 \mathrm{~b} / 100 \mathrm{ft}^{2}\right)$ while gel strength $\mathrm{G} 10_{\min }$. ranged between (12 to $231 \mathrm{~b} / 100 \mathrm{ft}^{2}$ ) and thixotropy was approximately constant at $2 \mathrm{~b} / 100 \mathrm{ft}^{2}$

From the above result we can consider that $(0.7 \mathrm{~g})$ of prepared polymer $\mathrm{S}_{1}$ as a selected concentration which represents the concentration at which rheological properties of the mud are compatable with API specification .

The rheological properties of the water-based mud formulated of $6 \%$ Local non-treated bentonite and different concentrations of the prepared polymer $\mathrm{S}_{2}$ ranged from 0.1 to $0.9 \mathrm{mg}\left(\mathrm{S}_{2}\right)$ were illustrated in Table 7 .

From the above results we can conclude that water-based muds which consist of $6 \%$ Local non-treated bentonites and different concentrations of the prepared polymer $S_{2}$ ranged from 0.1 to $0.9 \mathrm{~g}$. The rheological properties: Apparent viscosity (AV) increased from $(11.5$ to $21.5 \mathrm{cP})$. Plastic viscosity $(\mathrm{PV})$ increased from $(3$ to $5 \mathrm{cP})$. 
TABLE 7. The rheological properties of water based - mud formulated of local bentonite with different concentration of the new prepared polymer $S_{2}$.

\begin{tabular}{|c|c|c|c|c|c|c|c|}
\hline \multirow{2}{*}{$\begin{array}{l}\text { Mud } \\
\text { type }\end{array}$} & \multirow{2}{*}{$\begin{array}{c}\text { Conc. of } \\
\mathrm{S}_{2}(\mathrm{~g})\end{array}$} & \multirow[t]{2}{*}{$\mathrm{AV}(\mathbf{c P})$} & \multirow[t]{2}{*}{$\mathbf{P V}(\mathbf{c P})$} & \multirow{2}{*}{$\begin{array}{l}\mathrm{YP}(1 \mathrm{~b} / \\
\left.100 \mathrm{ft}^{2}\right)\end{array}$} & \multicolumn{2}{|c|}{$\begin{array}{c}\text { Gel } \\
\text { strength }(1 \mathrm{~b} / 100 \mathrm{ft} 2)\end{array}$} & \multirow{2}{*}{$\begin{array}{l}\text { Thixtropy } \\
\left(1 \mathrm{~b} / 100 \mathrm{ft}^{2}\right)\end{array}$} \\
\hline & & & & & G10 sec. & G10 min. & \\
\hline \multirow{9}{*}{$\mathbf{M S}_{\mathbf{2}}$} & 0.1 & 11.5 & 3 & 17 & 10 & 11 & 1 \\
\hline & 0.2 & 13.5 & 2 & 23 & 11 & 13 & 2 \\
\hline & 0.3 & 15 & 2 & 26 & 12 & 14 & 2 \\
\hline & 0.4 & 16 & 3 & 26 & 16 & 18 & 2 \\
\hline & 0.5 & 17.5 & 3 & 29 & 18 & 20 & 2 \\
\hline & 0.6 & 18.5 & 4 & 29 & 20 & 22 & 2 \\
\hline & 0.7 & 19 & 3 & 32 & 22 & 24 & 2 \\
\hline & 0.8 & 20 & 3 & 34 & 24 & 26 & 2 \\
\hline & 0.9 & 21.5 & 5 & 33 & 24 & 26 & 2 \\
\hline
\end{tabular}

Yield point (YP) increased from (17 to $331 \mathrm{~b} / 100 \mathrm{ft}^{2}$ ) as the concentrations of the prepared polymer $\mathrm{S}_{2}$ increased from $(0.1$ to $0.9 \mathrm{~g})$. The gel strength G10 ${ }_{\text {sec }}$.ranged between $\left(10\right.$ to $\left.241 \mathrm{~b} / 100 \mathrm{ft}^{2}\right)$ while gel strength $\mathrm{G} 10_{\min }$. ranged between $\left(11\right.$ to $\left.261 \mathrm{~b} / 100 \mathrm{ft}^{2}\right)$ and thixotropy was approximately constant at 2 $1 \mathrm{~b} / 100 \mathrm{ft}^{2}$. . From the above result we can consider that $(0.3 \mathrm{~g})$ of prepared polymer $\mathrm{S}_{2}$ as a selected concentration represents the concentration at which the rheological properties of the water based mud are compatable with API specification .

The rheological properties of the water-based mud formulated of $6 \%$ Local non-treated bentonites and different concentrations of the prepared polymer $\mathrm{S}_{3}$ ranged from 0.1 to $0.9 \mathrm{mg}\left(\mathrm{S}_{3}\right)$ were illustrated in Table 8 .

From the above results we can conclude that water-based mud which consist of $6 \%$ Local non-treated bentonite and different concentrations of the prepared polymer $\mathrm{S}_{3}$ ranged from 0.1 to $0.9 \mathrm{~g}$. the rheological properties : Apparent viscosity (AV) increased from (10 to $18 \mathrm{cP})$, Plastic viscosity (PV) increased from (2 to $3 \mathrm{cP}$ ) Yield point (YP) increased from (16 to $\left.301 \mathrm{~b} / 100 \mathrm{ft}^{2}\right)$ as the concentrations of the prepared polymer $S_{2}$ increased from $(0.1$ to $0.9 \mathrm{~g})$. The gel strength $\mathrm{G} 10_{\mathrm{sec}}$. ranged between $\left(10\right.$ to $\left.121 \mathrm{~b} / 100 \mathrm{ft}^{2}\right)$ while gel strength $\mathrm{G} 10_{\min }$. ranged between (12 to $\left.151 \mathrm{~b} / 100 \mathrm{ft}^{2}\right)$ and thixotropy changed from 2 to 3 $1 \mathrm{~b} / 100 \mathrm{ft}^{2}$. From the above result we can consider that $(0.5 \mathrm{~g})$ of prepared polymer $\mathrm{S}_{3}$ as a selected concentration represents the concentration at which the rheological properties of the mud are compatable with API specification . 
TABLE 8. The rheological properties of water based - mud formulated of local bentonite with different concentration of the new prepared polymer $S_{3}$.

\begin{tabular}{|c|c|c|c|c|c|c|c|}
\hline \multirow{2}{*}{$\begin{array}{l}\text { Mud } \\
\text { type }\end{array}$} & \multirow{2}{*}{$\begin{array}{l}\text { Conc. of } \\
S_{3}(g)\end{array}$} & \multirow[t]{2}{*}{$\mathrm{AV}(\mathrm{cP})$} & \multirow[t]{2}{*}{$\mathbf{P V}(\mathbf{c P})$} & \multirow{2}{*}{$\begin{array}{l}\text { YP(1b/ } \\
\left.100 f^{2}\right)\end{array}$} & \multicolumn{2}{|c|}{$\begin{array}{c}\text { Gel stranght } \\
(1 \mathrm{~b} / 100 \mathrm{ft} 2)\end{array}$} & \multirow{2}{*}{$\begin{array}{l}\text { Thixtropy } \\
\left(\mathbf{1 b} / \mathbf{1 0 0 \mathrm { ft } ^ { 2 }}\right)\end{array}$} \\
\hline & & & & & G10min & G10sec. & \\
\hline \multirow{9}{*}{$\mathbf{M S}_{\mathbf{3}}$} & 0.1 & 10 & 2 & 16 & 10 & 12 & 2 \\
\hline & 0.2 & 11 & 2 & 18 & 10 & 12 & 2 \\
\hline & 0.3 & 12.5 & 2 & 21 & 11 & 13 & 2 \\
\hline & 0.4 & 14 & 3 & 22 & 11 & 13 & 2 \\
\hline & 0.5 & 15 & 2 & 26 & 12 & 13 & 1 \\
\hline & 0.6 & 15.5 & 1 & 29 & 11 & 13 & 2 \\
\hline & 0.7 & 16.5 & 2 & 29 & 12 & 13 & 1 \\
\hline & 0.8 & 17 & 2 & 30 & 11 & 14 & 3 \\
\hline & 0.9 & 18 & 3 & 30 & 12 & 15 & 3 \\
\hline
\end{tabular}

Effect of temperature on the rheological properties of water-based mud

In our study, the rheological properties of water-based mud change with increasing temperature ranging between $60^{\circ} \mathrm{F}$ and $200^{\circ} \mathrm{F}$. For water-based mud consisting of local bentonite and treated with the new blending polymers $S_{1}, S_{2}$, $\mathrm{S}_{3}$ we selected $0.7 \mathrm{gm}$ of $\mathrm{S}_{1}, 0.3 \mathrm{gm}$ of $\mathrm{S}_{2}$ and $0.5 \mathrm{gm}$ of $\mathrm{S}_{3}$ as optimum concentration for the coreesponding water-based mud formulation $\mathrm{MS}_{1}, \mathrm{MS}_{2}$ and $\mathrm{MS}_{3}$ and then study the effect of temperature on the rheological properties as the temperature increasing ranging between $60{ }^{\circ} \mathrm{F}$ and $200{ }^{\circ} \mathrm{F}$ comparing the result with MR mud batch (Fig 3-5) showed that :

For $\mathrm{M}_{\mathrm{R}}$ :the apparent viscosity decreased from $19 \mathrm{cP}$ to $10 \mathrm{cP}$ while the plastic viscosity decreased from $15 \mathrm{cP}$ to $7 \mathrm{cP}$ and the yield point also changed from $8 \mathrm{lb} / 100 \mathrm{ft}^{2}$ to $6 \mathrm{lb} / 100 \mathrm{ft}^{2}$.

Effect of temperature on gel strength

For mud treated with imported viscosifier $\left(\mathrm{M}_{\mathrm{R}}\right)$, Fig. $6 \& 7$ revealed that the gel strength $\mathrm{G} 10$ sec. decreased from $5 \mathrm{lb} / 100 \mathrm{ft}^{2}$ to $3 \mathrm{lb} / 100 \mathrm{ft}^{2}$ after the temperature raised from $60^{\circ} \mathrm{F}$ to $200^{\circ} \mathrm{F}$. Also, G10 min decreased from $5 \mathrm{lb} / 100 \mathrm{ft}^{2}$ to $3 \mathrm{lb} / 100 \mathrm{ft}^{2}$ after $10 \mathrm{~min}$. Mud treated with the new viscosifier as the temperature rose from $60^{\circ} \mathrm{F}$ to $200^{\circ} \mathrm{F}$ :

$\mathrm{MS}_{1}$ : The gel strength decreased from $13 \mathrm{lb} / 100 \mathrm{ft}^{2}$ to $9 \mathrm{lb} / 100 \mathrm{ft}^{2}$, after $10 \mathrm{sec}$, also it decreased from $13 \mathrm{lb} / 100 \mathrm{ft}^{2}$ to $9 \mathrm{lb} / 100 \mathrm{ft}^{2}$ after $10 \mathrm{~min}$ as the temperature raised from $60^{\circ} \mathrm{F}$ to $200^{\circ} \mathrm{F}$.

$\mathrm{MS}_{2}$ : The gel strength decreased from $13 \mathrm{lb} / 100 \mathrm{ft}^{2}$ to $5 \mathrm{lb} / 100 \mathrm{ft}^{2}$, after 10 sec,also it decreased from $13 \mathrm{lb} / 100 \mathrm{ft}^{2}$ to $5 \mathrm{lb} / 100 \mathrm{ft}^{2}$ after $10 \mathrm{~min}$ as the temperature raised from $60^{\circ} \mathrm{Fto} 200^{\circ} \mathrm{F}$.

$\mathrm{MS}_{3}$ : The gel strength decreased from $13 \mathrm{lb} / 100 \mathrm{ft}^{2}$ to $9 \mathrm{lb} / 100 \mathrm{ft}^{2}$, after $10 \mathrm{sec}$, also it decreased from $13 \mathrm{lb} / 100 \mathrm{ft}^{2}$ to $9 \mathrm{lb} / 100 \mathrm{ft}^{2}$ after $10 \mathrm{~min}$ as the temperature raised from $60^{\circ} \mathrm{F}$ to $200^{\circ} \mathrm{F}$. 


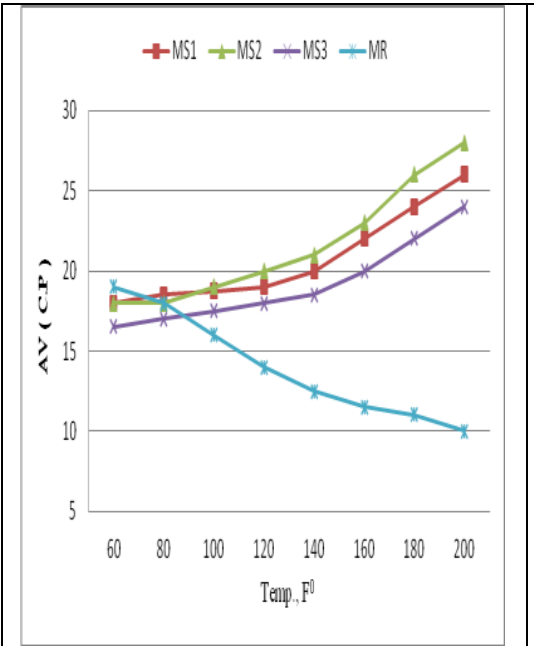

Fig. 3. Apparent viscosity-temperature relation of $\mathrm{MS}_{1}, \mathrm{MS}_{2}$ and $\mathrm{MS}_{3}$ compared to reference mud sample $\left(\mathbf{M}_{R}\right)$.

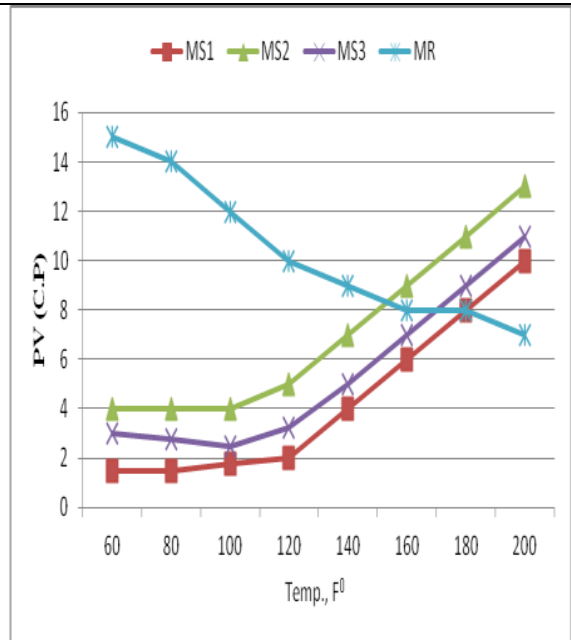

Fig. 4. Plastic viscosity-temperature relation of $\mathrm{MS}_{1}$, $\mathrm{MS}_{2}$ and $\mathrm{MS}_{3}$ compared to reference mud sample $\left(\mathbf{M}_{\mathbf{R}}\right)$.

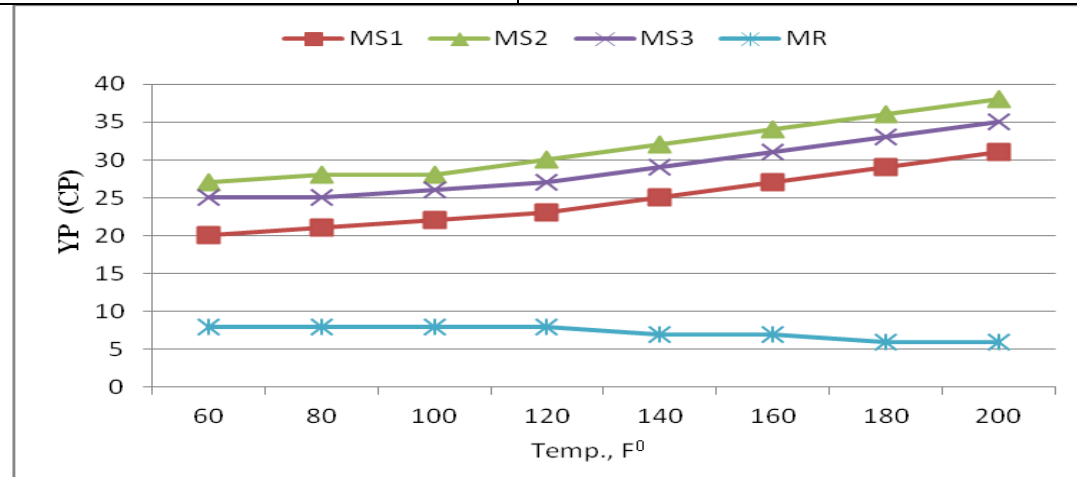

Fig. 5. Yield point -temperature relation of $\mathrm{MS}_{1}, \mathrm{MS}_{2}$ and $\mathrm{MS}_{3}$ compared to reference mud sample $\left(\mathbf{M}_{\mathrm{R}}\right)$.

MS $_{1}$ : The apparent viscosity increased from $19.5 \mathrm{cP}$ to $26 \mathrm{cP}$, plastic viscosity increased form $2 \mathrm{cP}$ to $10 \mathrm{cP}$ and yield point increased from $26 \mathrm{lb} / 100 \mathrm{ft}^{2}$ to $31 \mathrm{lb} / 100 \mathrm{ft}^{2}$.

$\mathbf{M S}_{2}$ : The apparent viscosity increased from $20 \mathrm{cP}$ to $28 \mathrm{cP}$, the plastic viscosity increased from $5 \mathrm{cP}$ to $13 \mathrm{cp}$ and yield point increased from $23 \mathrm{lb} / 100 \mathrm{ft}^{2}$ to $38 \mathrm{lb} / 100 \mathrm{ft}^{2}$.

MS $_{3}$ : The apparent viscosity increased from $16.5 \mathrm{cP}$ to $24 \mathrm{cP}$, the plastic viscosity increased from $3 \mathrm{cP}$ to $4 \mathrm{cP}$ and yield point increased from $8 \mathrm{lb} / 100 \mathrm{ft}^{2}$ to $6 \mathrm{lb} / 100 \mathrm{ft}^{2}$.

Results of the rheology-temperature relation indicate that the new additives $\mathrm{S}_{1}, \mathrm{~S}_{2}$ and $\mathrm{S}_{3}$ satisfy the minimum requirements for API specification compared to imported viscosifier $M_{R}$.

Egypt. J. Chem. 59, No. 1 (2016) 


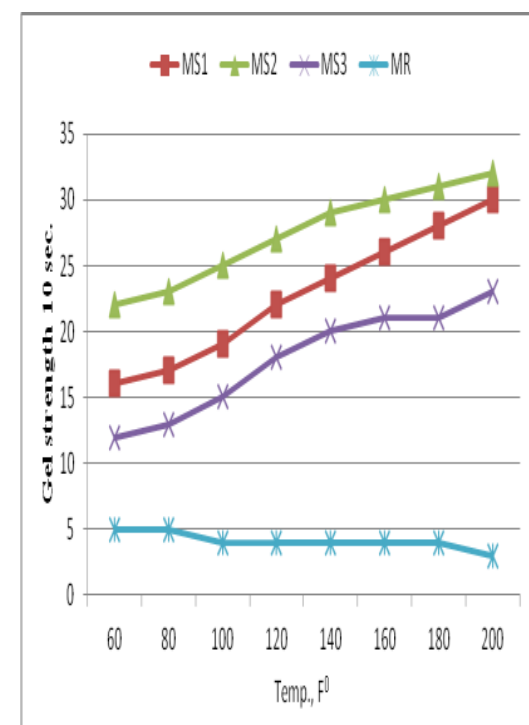

Fig. 6. gel strength10 sec.-temperature relation of $\left(\mathrm{MS}_{1}, \mathrm{MS}_{2}, \mathrm{MS}_{3}\right)$ compared to reference mud sample $\left(M_{R}\right)$.

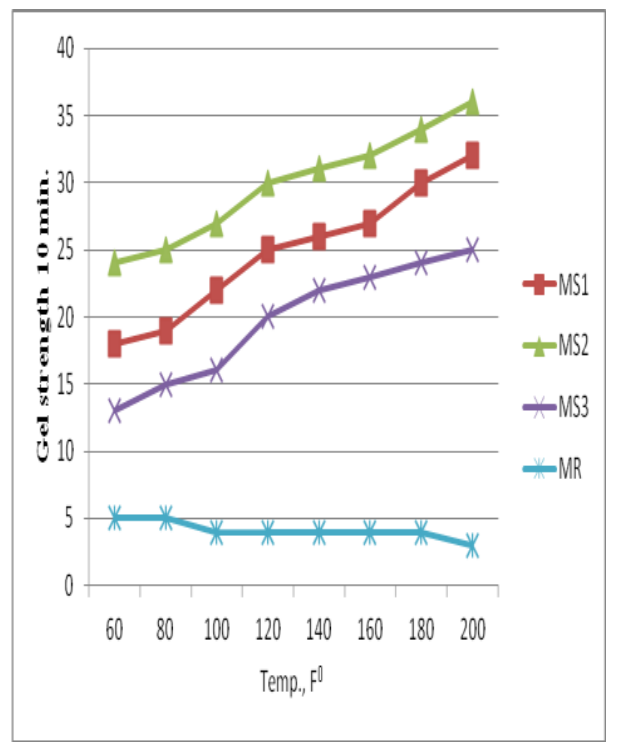

Fig. 7. Gel strength10 mints.-temperature relation of $\left(\mathrm{MS}_{1}, \mathrm{MS}_{2}, \mathrm{MS}_{3}\right)$ compared to reference mud sample $\left(\mathrm{M}_{\mathrm{R}}\right)$.

TABLE 9. Thixtropy for MS1, MS2, MS3 compared to MR with increasing temperature .

\begin{tabular}{|c|c|c|c|c|}
\hline Temp. $\mathbf{F}^{\mathbf{0}}$ & $\mathbf{M S}_{\mathbf{1}}$ & $\mathbf{M S}_{\mathbf{2}}$ & $\mathbf{M S}_{\mathbf{3}}$ & $\mathbf{M}_{\mathbf{R}}$ \\
\hline $\mathbf{6 0}$ & 2 & 2 & 1 & 0 \\
\hline $\mathbf{8 0}$ & 2 & 2 & 2 & 1 \\
\hline $\mathbf{1 0 0}$ & 3 & 2 & 1 & 0 \\
\hline $\mathbf{1 2 0}$ & 3 & 3 & 2 & 1 \\
\hline $\mathbf{1 4 0}$ & 2 & 3 & 2 & 0 \\
\hline $\mathbf{1 6 0}$ & 1 & 2 & 2 & 0 \\
\hline $\mathbf{1 8 0}$ & 2 & 2 & 3 & 1 \\
\hline $\mathbf{2 0 0}$ & 2 & 1 & 2 & 0 \\
\hline
\end{tabular}

From Table 9 it is clear that thixotropy of water-based mud MS1, MS2, and MS3 compared to the reference mud batch MR as the temperature increased the thixotropy increased for the mud batches treated with the new blending polymers while the thixotropy of the reference mud kept the value of thixotropy .

Relationship between shear stress and shear rate of water-based mud

For mud treated with imported viscosifier $\mathrm{M}_{\mathrm{R}}$ : At $80{ }^{\circ} \mathrm{F}$ the value of shear stress decreased from 36 to $41 \mathrm{~b} / \mathrm{ft}^{2}$ as the shear rate decreased from $1020 \mathrm{sec}^{-1}$ to $5.1 \mathrm{sec}^{-1}$. At $140{ }^{\circ} \mathrm{F}$ the value of shear stress decreased from 25 to $31 \mathrm{~b} / \mathrm{ft}^{2}$ as the shear rate decreased from $1020 \mathrm{sec}^{-1}$ to $5.1 \mathrm{sec}^{-1}$. At $200{ }^{\circ} \mathrm{F}$ the value of shear stress decreased from 20 to $2 \mathrm{~b} / \mathrm{ft}^{2}$ as the shear rate decreased from $1020 \mathrm{sec}^{-1}$ to 
$5.1 \mathrm{sec}^{-1}$. $\quad \mathrm{MS}_{1}$ : At $80{ }^{\circ} \mathrm{F}$ the value of shear stress decreased from 37.5 to 13 $1 \mathrm{~b} / \mathrm{ft}^{2}$ as the shear rate decreased from $1020 \mathrm{sec}^{-1}$ to $5.1 \mathrm{sec}^{-1}$. At $140{ }^{\circ} \mathrm{F}$ the value of shear stress decreased from 40 to $131 \mathrm{~b} / \mathrm{ft}^{2}$ as the shear rate decreased from $1020 \mathrm{sec}^{-1}$ to $5.1 \mathrm{sec}^{-1}$. At $200{ }^{\circ} \mathrm{F}$ the value of shear stress decreased from 52 to $18 \mathrm{bb} / \mathrm{ft}^{2}$ as the shear rate decreased from $1020 \mathrm{sec}^{-1}$ to $5.1 \mathrm{sec}^{-1} . \mathrm{MS}_{2}$ : At $80{ }^{\circ} \mathrm{F}$ the value of shear stress decreased from 39.5 to $131 \mathrm{~b} / \mathrm{ft}^{2}$ as the shear rate decreased from $1020 \mathrm{sec}^{-1}$ to $5.1 \mathrm{sec}^{-1}$. At $180{ }^{\circ} \mathrm{F}$ the value of shear stress decreased from 41.5 to $91 \mathrm{~b} / \mathrm{ft}^{2}$ as the shear rate decreased from $1020 \mathrm{sec}^{-1}$ to 5.1 $\mathrm{sec}^{-1}$. At $200{ }^{\circ} \mathrm{F}$ the value of shear stress decreased from 56 to $181 \mathrm{~b} / \mathrm{ft}^{2}$ as the shear rate decreased from $1020 \mathrm{sec}^{-1}$ to $5.1 \mathrm{sec}^{-1}$. $\mathrm{MS}_{3}$ : At $80{ }^{\circ} \mathrm{F}$ the value of shear stress decreased from 34 to $4 \mathrm{~b} / \mathrm{ft}^{2}$ as the shear rate decreased from 1020 $\mathrm{sec}^{-1}$ to $5.1 \mathrm{sec}^{-1}$. At $180{ }^{\circ} \mathrm{F}$ the value of shear stress decreased from 36 to $31 \mathrm{~b} / \mathrm{ft}^{2}$ as the shear rate decreased from $1020 \mathrm{sec}^{-1}$ to $5.1 \mathrm{sec}^{-1}$. At $200{ }^{\circ} \mathrm{F}$ the value of shear stress decreased from 48 to $2 \mathrm{~b} / \mathrm{ft}^{2}$ as the shear rate decreased from 1020 $\mathrm{sec}^{-1}$ to $5.1 \mathrm{sec}^{-1}$. Figure 8 illustrated that the value of shear stress decreased as shear rate decreased at same temperature.
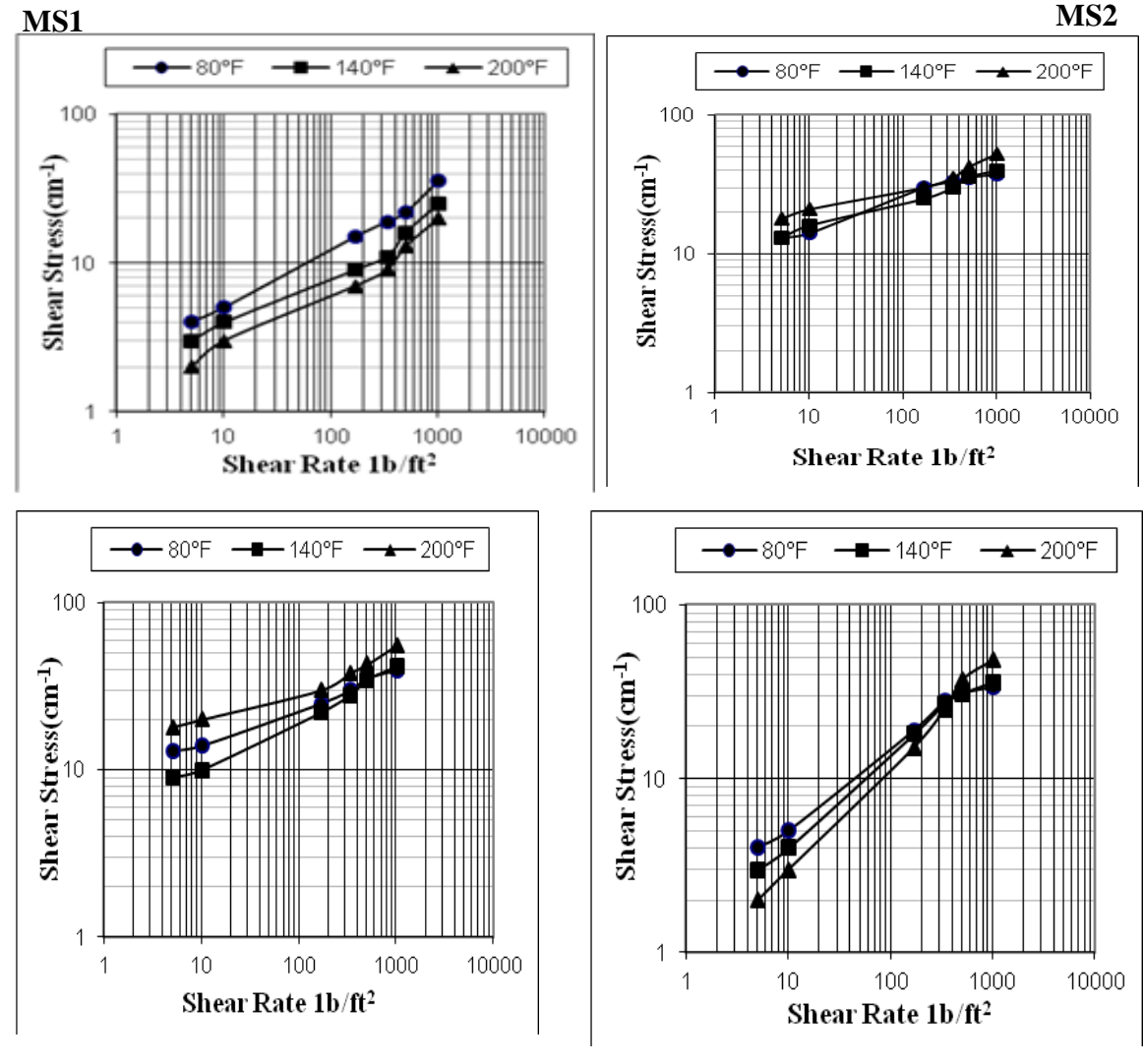

MS3

Shear Rate

MR

Fig. 8. shere rate - shear stress relationship of MS1, MS2, MS3 compared to MR .

Egypt. J. Chem. 59, No. 1 (2016) 
Effective viscosity of water-based mud

Plotting viscosity of mud versus the value of shear rate are illustrated in Fig. 9. The testing result showed that : the effective viscosity of the mud decreased with increased shear rate, these results are similar to field mud $\left(M_{R}\right)$ formulated with the reference mud. From Fig. 9 we conclude that: the values of the effective viscosity verses the shear rate of water-based mud treated with the new prepared blending polymers $S_{1}, S_{2}$ and $S_{3}$ are extremely shear thining.

MS1
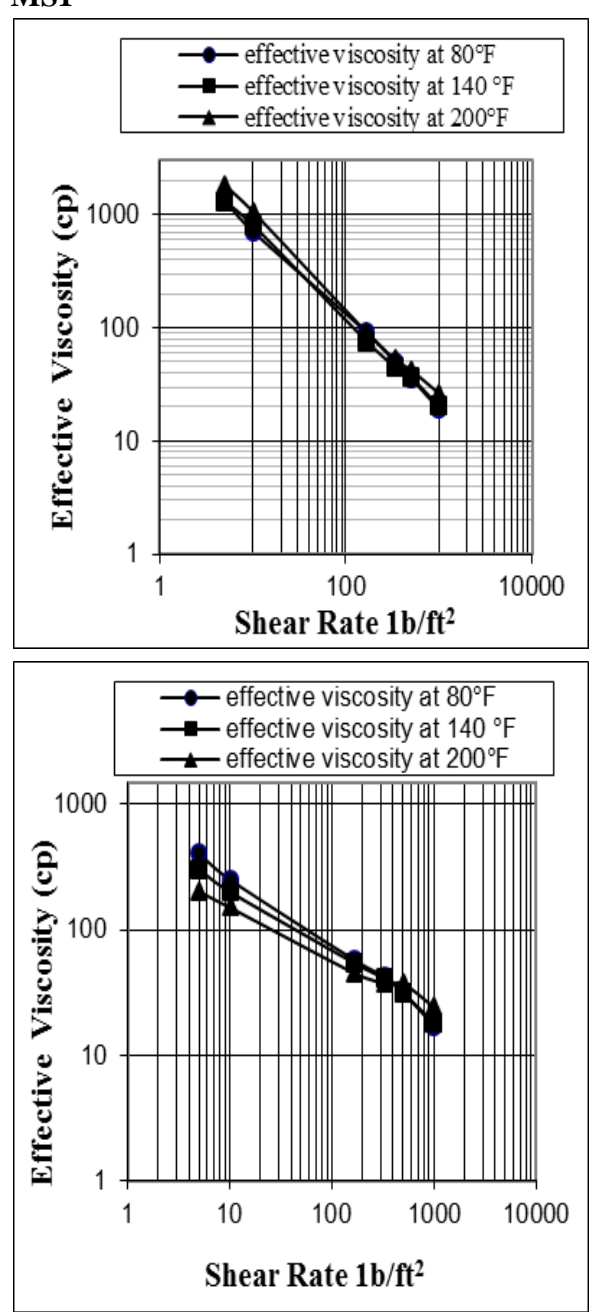

MS3
MS2
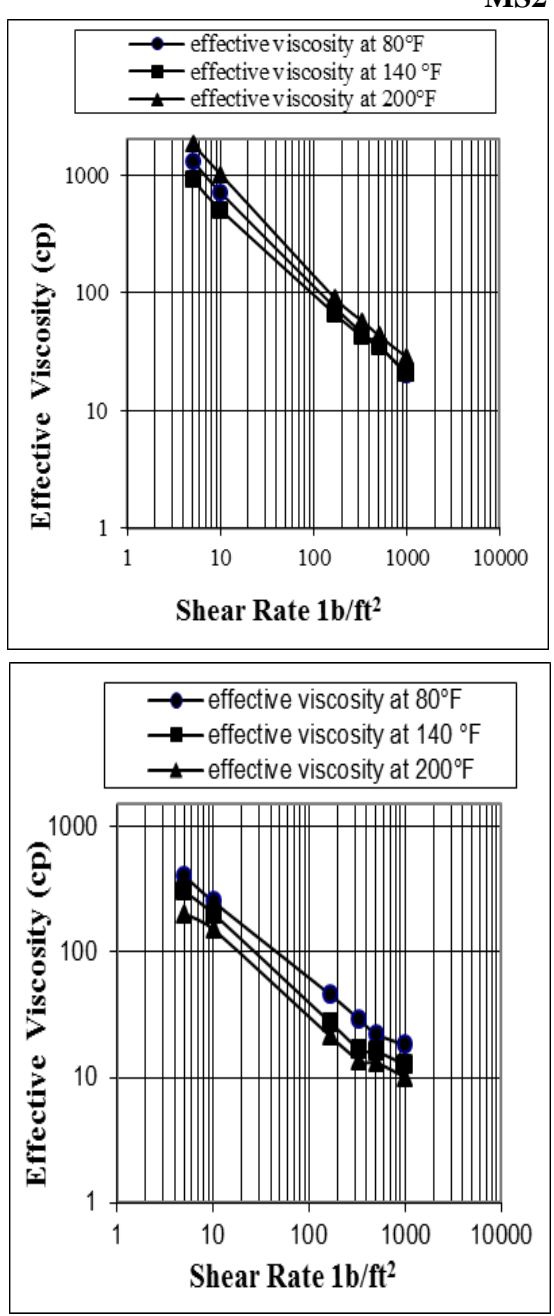

MR

Fig. 9. Effective viscosity of MS1, MS2, MS3 compared to MR with different temperature . 
Filtration properties of water-based mud

As shown in Table 10 the stander filter loss at 100 psi after 30 min was measured and the corrected filter loss was determined for $\mathrm{MS}_{1}, \mathrm{MS}_{2}$ and $\mathrm{MS}_{3}$ compared to $\mathrm{M}_{\mathrm{R}}$ and Mo. The results of the filtration test showed that the higher filter loss for $\mathrm{M}_{0}$ cannot meet API specification, while the filter loss of the mud batches $\mathrm{MS}_{1}, \mathrm{MS}_{2}$ and $\mathrm{MS}_{3}$ was compatable to the API specification and less than reference mud sample $M_{R}$.

TABLE 10. Stander fluid-loss for $\mathrm{MS}_{1}, \mathrm{MS}_{2}, \mathrm{MS}_{3}$ compared to $\mathrm{M}_{\mathrm{R}}$ and $\mathrm{M}_{0}$.

\begin{tabular}{|l|c|c|}
\hline Mud & Filter cake description & Fluid-loss $(\mathbf{m l})$ \\
\hline $\mathrm{M}_{\mathrm{R}}$ & Filter cake thickness $(\mathrm{mm})=1.4$ & 15 \\
\hline $\mathrm{M}_{\mathbf{0}}$ & Filter cake thickness $(\mathrm{mm})=1.4$ & 25 \\
\hline $\mathrm{MS}_{1}$ & Filter cake thickness $(\mathrm{mm})=0.9$ & 14.5 \\
\hline $\mathrm{MS}_{2}$ & Filter cake thickness $(\mathrm{mm})=0.9$ & 14 \\
\hline $\mathrm{MS}_{3}$ & Filter cake thickness $(\mathrm{mm})=0.9$ & 13.5 \\
\hline
\end{tabular}

Application of the power law model to the rotary viscometer data

The flow behavior index (n) and consistency index (K) values are calculated according to the power law model Herschel-Buckley model and is given by : $\mathrm{T}_{\mathrm{T}}={ }_{\mathrm{T}_{\mathrm{p}}}+\mathbf{k} \cdot \mathrm{r}^{\mathrm{n}}(\mathbf{4 0 )}$.

$\mathrm{T}=$ shear stress

$T_{\mathrm{T}}=$ yield stress or yield point

$\mathrm{K}=$ the consistency factor (viscosity in case of a newtonian or bingham fluid)

$\mathrm{r}=$ share rate

$\mathrm{n}=$ the power of low exponent (rate index ) or flow behavior.

Table 11 illustrated the flow behavior index (n) and the consistency index (k) of $\mathrm{Mc}$ and $\mathrm{M}_{\mathrm{R}}$.

TABLE 11. The flow behavior index(n) and consistency index $(K)$.

\begin{tabular}{|c|c|c|c|c|c|}
\hline $\begin{array}{l}\text { Mud } \\
\text { type }\end{array}$ & $\begin{array}{c}\text { Concentration } \\
\text { of blending } \\
\text { polymer g/500 } \\
\text { cm3 base mud }\end{array}$ & $\begin{array}{c}\text { Dial } \\
\text { reading } \\
\text { at } 600 \\
\text { rpm }\end{array}$ & $\begin{array}{c}\text { Dial } \\
\text { reading } \\
\text { at } 300 \\
\text { rpm }\end{array}$ & $\begin{array}{c}\text { Flow behavior } \\
\text { index(n)dimensionless }\end{array}$ & $\begin{array}{l}\text { Consistency } \\
\text { index } \\
\text { (K)lb.sec }{ }^{\mathrm{n}} / \mathbf{f t}^{2}\end{array}$ \\
\hline $\mathrm{M}_{\mathrm{R}}$ & 0 & 30 & 20 & 0.585 & 0.523 \\
\hline $\mathrm{M}_{\mathrm{S} 1}$ & 0.7 & 30 & 28 & 0.470 & 1.401 \\
\hline $\mathrm{M}_{\mathrm{S} 2}$ & 0.3 & 35 & 28 & 0.322 & 3.768 \\
\hline $\mathrm{M}_{\mathrm{S} 3}$ & 0.5 & 30 & 26 & 0.322 & 3.768 \\
\hline
\end{tabular}

\section{Conclusion}

The characterization of non activated clays collected from South Hamam , Egypt for the application as a drilling fluid ( water-based mud ) was investigated. Also, the activation compatibility for these clays was explained as an attempt to minimize the important cost of the imported bentonite to Egypt by a local solution. The following main conclusion can be drawn from the present study:

Egypt. J. Chem. 59, No. 1 (2016) 
1. Most of the studied samples of bentonite clay, were mainly $\mathrm{Na}$ montmorillonite:

2. The studied non - activated samples cannot be used as a drilling mud without activation.

3. The studied clay samples can be used after activation with the blending polymers $S_{1}, S_{2}$, and $S_{3}$, as drilling fluids for its rheological properties satisfied the API standard and OCMA specification .

4. The obtained results revealed that the activated samples may be expressed as medium grade bentonite clays and these grades of clay can be used as drilling fluids for shallow depth wells.

5. The structures of the samples $\mathrm{S} 1$ and $\mathrm{S} 2$ have similar structures (cross linked polymers) but differ in the amount of NVP which are 4.5 and 6, respectively. The structure of the other sample S3 was different from that of S1 and S2 because it is a linear polymer (without cross linker).

The effects of all the samples were studied and showed that the efficiency increases in the order of cross linked polymers more than linear polymer and decreases by increasing the amount of NVP in all samples, S2 $>$ S1 $>$ S3 and this result is compatable with the minorolegical study for the water based mud which formulated from local bentonite sample and treated with the blending polymers $\mathrm{S}_{1}, \mathrm{~S}_{2}$, and $\mathrm{S}_{3}$

6. Rheological, filtration properties of the water - based mud treated with the new prepared viscosifier performed a superior results compared to the commercial viscosifier .

\section{References}

1. Ryen Caenn and Chillingar George V., Drilling fluids: State of the art. Journal of Petroleum Science and Engineering, I4, 22 1-230 (1996).

2. Morita, N., Black., A.D. and Fuh, G-F., Borehole breakdown pressure with drilling fluids-I. Empirical results. International Journal of Rock Mechanics and Minning Science. Geomechanics, 33 (1), 39-51 (1996).

3. Lagaly, G., Bergaya, F. and Theng, B.K.G., Handbook of Clay Science. ( $1^{\text {st }}$ ed.) Elsevier, ISSN 1572-4352 Colloidal clay science. Pages 141-246. Chapter 5, (2006).

4. Darley, H. and Gray. G., Composition and Properties of Drilling and Completion Fluids, fifth edition, Gulf Professional Publishing, Oxford, (1988).

5. Ahmed, S.M., Aiad, I. and Dardir, M.M., Synthesis and some applications of anionic palmitic acid schiff base salt surfactants. J. American Sci. 7 (1), $799-807$ (2011).

6. Dardir, M.M., Ibrahime, M., Aqel, M.R., Madkour, H.M. and Hafiz, A.A., Environmentally safed synthetic mud for oil-well drilling fluids. Mansoura Journal of Chemistry, 37 (2), 245-272 (2010). 
7. Dardir, M.M., Ibrahime, S., Soliman, M., Desouky, S.D. and Hafiz, A.A., Preparation and evaluation of some esteramides as synthetic based drilling fluids. Egyptian Journal of Petroleum, 23, 35-43 (2014).

8. Dardir, M.M. and Mahmmoud, S.A. Synthesis and Evaluation of a new cationic surfactant for oil-well drilling fluids. J. Surfactant and Detergent. 14, 123-130 (2010).

9. Dardir, M.M., Mahmmoud, S.A. and Ghuiba F.M., Synthesis and evaluation of novel polymeric phosphates surfactant for oil-based mud. J. Desperation science and Technology, 31, 1011-1018 (2010).

10. Dardir, M.M. and Abdou, M.I., Ether-based muds show promise for replacing some oil-based muds. Petroleum Science and Technology, 31, 2335-2347 (2013).

11. Dardir, M.M. and Hafiz, A.A., Ester amide as an environmentally friendly syntheticbased drilling fluids. J. American Science, 9 (6), 133-142 (2013).

12. Christidis, G. and Huff, D.H., Geologic aspects and genesis of bentonites. Journal of Elements, 5 (2), 93-98., (2009).

13. Güven, N. and Bailey, S.W., Smectites in hydrous phyllosilicates reviews in mineralogy. Journal of Mineralogical Society of America, 19, 497-559 (1988).

14. Eisenhour, D.D. and Brown, R.K., Bentonite and its impact on modern life. Journal of Elements, $\mathbf{5}$ (2), 83-88 (2009).

15. Guangming, Chen, Buxing, Han and Haike, Yan, Interaction of cationic surfactants with iron and sodium montmorillonite suspensions. Journal of Colloid and Interface Science, 201 (2), 158-163 (1998). Thaemlitz, C.J., Patel, A.D., George Coffin and Lee Conn, New environmentally safe high temperature water-based drilling fluid system. SPE 57715, (1999)

16. Nevin, Öztekin., Sevim, İşci., Bedia Erim, F., Nurfer and Güngör. Effect of the adsorption of cetylpyridinium bromide on the flow behaviour of bentonite dispersions. Journal of Materials. Letters, 57 (3), 684-688 (2002).

17. Sevim, I., Seniha Gu ner, F., Is, Ik Ece, O. and Nurfer Gungor, Investigation of rheological and collodial properties of bentonitic clay dispersion in the presence of a cationic surfactant. Journal Progress in Organic Coatings, 54, 28-33 (2005)

18. Dardir M.M., Badwi A.M. and Ahmed, H.M., Synthesis and evaluation of novel cationic monomers viscosifiers for oil well drilling fluids. Journal of American Science, 7 (1), 473-484 (2011).

19. Apaleke, Sanmi, Adeleye, Al-Majed, Abdulaziz and Enamul Hossain, M., Drilling fluid: state of the art and future trend", SPE 149555, North Africa Technical Conference and Exhibition in Cairo, Egypt, 20-22 February (2012).

20. Bol. G.M., Bentonite Quality and Evaluation Methods, Society of Petroleum Engineering Drilling Engineering 288-296 (1986).

Egypt. J. Chem. 59, No. 1 (2016) 
21. Luckham, P.F. and Rossi, S., The colloidal and rheological properties of bentonite suspensions. Journal of Advances in Colloid and Interface Science, 82 (50), 43-92 (1999).

22. API (American Petroleum Institute), Standard Procedures for Oil Field Testing, Recommended Practice 13B-1, Third Edtion, 13A Third Edition (1998).

23. Karagüzel. C., Çetinel, T., Boylu, F., Çinku, K. and Çelik, M.S., Activation of (Na, Ca)-bentonites with soda and $\mathrm{MgO}$ and their utilization as drilling mud. Journal of Applied Clay Science, 48, 398-404 (2010)

24. Moore, D.M. and Reynolds, Jr. R.C., X-ray Diffraction and the Identification and Analysis of Clay Minerals, Oxford University Press, Oxford (1997).

25. Jhe, O., Systems interstratified clay-water-electrolyte-xanthan. Journal of Colloid and Interface Science, 273, 675-684 (2004).

26. Lemi, J., Tomas, evi., Canov, M., Djuri ci, M. and Stani, T., Surface modification of sepiolite with quaternary amines. Journal of Colloid Interface Science. 292, 11-19 (2005).

27. Zamora, M., Broussard, P.N. and Stephens, M., The Top 10 Mud-Related Concerns in Deepwater drilling Operations." SPE 59019, SPE International Petroleum Conference, Villa Hermosa, Tabasco, Mexico, February 1-3 (2000).

28. Lei Wang, Shangying Liu, Tian Wang and Dejun Sun., Effect of poly (oxypropylene) diamine adsorption on hydration and dispersion of montmorillonite particles in aqueous solution. Journal of Colloids and Surfaces A, 381, 41-47, (2011)

29. Güngo $\mathbf{r}$.N. and. Karaog lan, S. Interactions of polyacrylamide polymer with bentonite in aqueous systems. Journal of Materials Letters 48, 168-175 (2001).

30. Tao Wan, Jie Yao, Sun Zishun, Wang Li. and Wang Juan, Solution and drilling fluid properties of water soluble AM-AA-SSS copolymers by inverse microemulsion. Journal of Petroleum Science and Engineering, 78, 334-337(2011)

31. Falode, O.A., Ehinola, O.A. and Nebeife. P.C., Evaluation of local bentonitic clay as oil well drilling fluids in Nigeria. Journal of Applied Clay Science, 39, 19-27 (2008).

32. Akc ay, G. and Yurdakoc, M.K., Nonyl- and dodecylamines intercalated bentonite and illite from Turkey. Turk J Chem. 23, 105 - 113 (1999).

33. Liu, X., Chen, Y., Huang, Q., He, W., Feng, Q. and Yu., B., A novel thermo sensitive hydrogel based onthiolated chitosan/hydroxyapatite/beta-glycerophosphate.Carbohydrate Polymers, 110, 62-69 (2014).

34. Liu, R., Xu, X., Zhuang, X. and Cheng, V., Solution blowing of chitosan/PVA hydrogel nanofiber mats. Carbohydrate Polymers, 101, 1116-1121 (2014).

35. Eid, M., El-Arnaouty, M. B., Salah, M., El-Sayed Soliman and El-Sayed A. Hegazy, Radiation synthesis and characterization of poly (vinyl alcohol) /poly (N-vinyl-2-

Egypt. J. Chem. 59, No. 1 (2016) 
pyrrolidone) based hydrogels containing silver nanoparticles. Journal of Polymer Research, 19 (3), 1-10 (2012).

36. Mondino A.V., Gonzalez M.E., Romero G.R. and Smolko E.E., Physics properties gamma irradiated poly(vinyl alcohol) hydrogel preparations. Radiat Phys Chem. 55, 723-726 (1999).

37. Dardir, M.M., Farag, A.B., Ramdan, A.M., Emam, D., Ahmed, H.E.S. and Fayed, M.M., Activation of Egyptian bentonite to improve their drilling fluids properties. International Journal of Current Research. 6 (5) , 6772-6780 , (2014b) .

38. Dardir, M.M., Abdou, M.I. and Al-Sabagh, A.M., Evaluation of Egyptian bentonite and nano- bentonite as drilling mud. Egyptian Journal of Petroleum, 22, 53-59 (2013 c) .

39. Oil Companies Materials Association (OCMA), Specification No. DFCP-4 ,Drilling fluid materials , The Institute of Pertoleum , London , PP. 5-9 (1983)

40. Hermoso, J., Martinez -Boza, F. and Gallagos C., Influence of viscosity modifier nature and concentration of the viscous flow behavior of oil-based drilling fluids at high pressure. J.Applied Clay Science , 87, 14-21 (2014) .

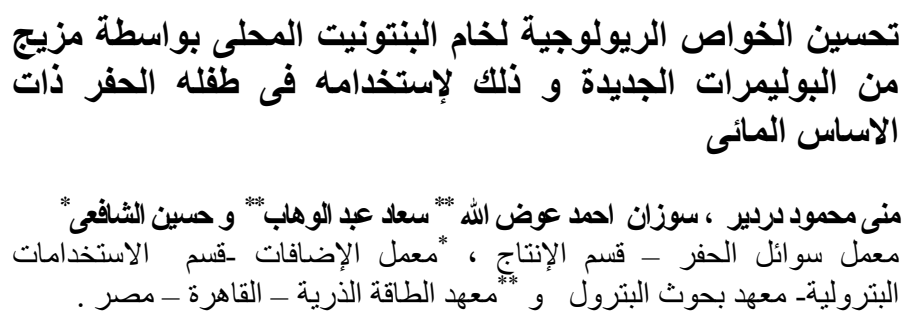

تم تحضير بوليمرات جديدة من تفاعل مخاليط مختلفة من البوليمرات باستخدام تقنية

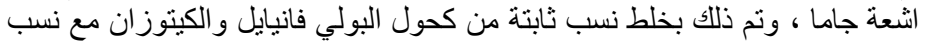

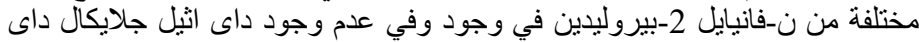

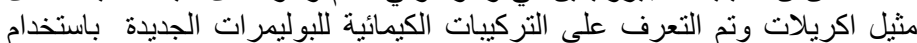

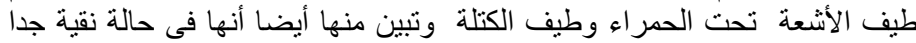

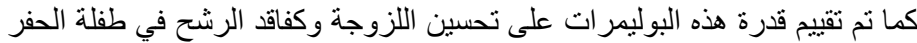

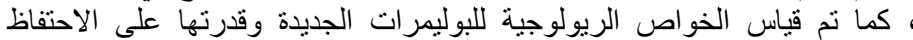

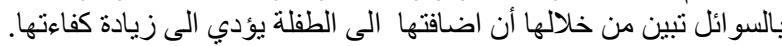


